\title{
The Multicultural Islamic Education Development Strategy on Educational Institutions
}

\author{
Hifza1, Antoni' ${ }^{2}$, Abdul Wahab Syakhrani ${ }^{3}$, Zainap Hartati ${ }^{4}$ \\ ${ }^{1}$ Institut Agama Islam Sultan Muhammad Syafiuddin Sambas, Indonesia \\ ,2 Universitas Wijaya Putra Surabaya, Indonesia \\ ,3 Sekolah Tinggi Agama Islam Rasyidiyah Khalidiyah Amuntai, Indonesia \\ ,4 Institut Agama Islam Negeri Palanga Raya, Indonesia
}

Corresponding Author: Zainap Hartati, zainap.hartati@iain-palangkaraya.ac.id

\author{
ARTICLE INFO \\ Article history: \\ Received \\ March, 272020 \\ Revised \\ May 18, 2020 \\ Accepted \\ June 07, 2020
}

\section{ABSTRACT}

\begin{abstract}
The aim of this study was to analyse the strategies for the development of multicultural Islamic education in Islamic educational institutions. It used literature studies based on a qualitative approach. The study showed that: the first the foundation of multicultural Islamic Education Development consists of religious, historical, psychological, sosiokultural and geographic foundations. Second, the Multicultural Islamic Education development strategy on Islamic educational institutions can be pursued through two approaches, namely quantitative and qualitative. Quantitative development strategy was with the socialization and internalization program through scientific activities, multicultural education innovation programs, and build a culture that accommodates the spirit and multicultural values in the environment of Islamic institutions. While the development strategy qualitative was the intensive study program of the Qur'an and Sunnah, curriculum revision programs, education and training programs for educators, and local wisdom programs.
\end{abstract}

Keywords: Development Strategy, Multicultural Islamic Education, Strategy on Educational Institution

How to cite Hifza, H., Antoni, A., Syakhrani, A., Hartati, Z. (2020). The Multicultural Islamic Education Development Strategy on Educational Institution. Jurnal Iqra' : Kajian Ilmu Pendidikan, 5(1). 158-170. https:// doi.org/10.25217/ji.v5i1.799 http://journal.iaimnumetrolampung.ac.id/index.php/ji/

Journal Homepage http://journal.iaimnumetrola
This is an open access article under the CC BY SA license https://creativecommons.org/licenses/by-sa/4.0/

Published by Institut Agama Islam Ma'arif NU (IAIMNU) Metro Lampung

\section{INTRODUCTION}

Indonesia is one of the largest multicultural potentials area in the world. It can be seen from the dynamics of diverse peoples ' lives, both in the religious aspects, ethnic groups, languages and Cultures (Mazid, 2017; Maksum, 2007). The diversity that exists, can actually be one of the great potential for the advancement of the nation. But on the other side, it also potentially raises various problems if not managed and developed properly and directly. Muslims as a majority religion, must play an active role in managing the dimension of diversity of this nation. Islamic education as one of the important instruments of civilization of the people, needs to be optimized as well as 
possible in order to organize the dynamics of diversity in order to become a potential progress.

Multicultural means ' cultural diversity (Ghosh, \& Galczynski, 2014). The term multicultural itself is formed from the word ' multi ' meaning plural; Many or diverse, and ' cultures ' which means culture (Muliadi, 2011). Cultures or cultures are the traits of human behaviour learned, not derived genetically and specifically, so that the culture of certain communities may differ from other cultures of society (Mulyono, 2019: Muhammad Al Farabi, 2018; Mujiburrahman (2017). In other words, culture is a distinctive characteristic for every individual (person) or a group (comunitee) that is very likely to differ from one another. In the educational law, the multicultural paradigm is implicitly mentioned in No. 20 of 2003, in chapter III of article 4, which discusses the principles of Education organizing (Irawati\& Susetyo, 2017). Through this article explained that the implementation of education must be held democratically, not discriminatory by upholding human rights, religious value, cultural value and the diversity of nations, in accordance with the basic values of the State, namely Pancasila. Meanwhile, in the context of multicultural Islamic Education development, recognition of all forms of diversity is certainly not enough, but how to treat diversity with the principle of justice. The dimension of ' diversity ' that becomes the essence of the multicultural concept and then develops into a movement called multiculturalism (Chin, 2019; Sahal et al., 2018). Indeed, efforts to accommodate and organize the dynamics of diversity through the agenda of Islamic education are pretty much done. There are not a few ideas or ideas about multicultural that are actualized in Islamic education discussions and practices. However, if viewed from the concept of development and implementation, it has not been running as expected. The implementation of multicultural Islamic education, especially in Islamic education institutions was still faced with various issues.

The problems include two aspects: first, quantitative aspect. Multicultural Islamic education has not been well-socialized and widely influenced by society, especially in the educational environment (Zein, 2014). Although the college level, especially in the environment of Perguruan Tinggi Keagamaan Islam (PTKI). The multiculturalism discourse has enough place, but at the school level of madrasah, the spirit and values of multiculturalism have not been widely socialized. Kurniallah \& Suharti, (2016) \& Arifin, (2018) reported that the conflict occurred in Indonesia was caused by diverse ethnic and based on the name of religion. Furthermore, Nuzliah (2016) declared that to avoid conflicts with ethnic and religious attributes should be provided by counselors to do guidance. In fact, The research Lee (2019) conducted by against women in the Africa which has the same ethnic still requires a briefing in order not to conflict. The second is qualitative aspect. Either in terms of concept or implementation in educational institutions, there are many parts that need to be addressed. Conceptually, the study of multicultural Islamic education has not been wellsystematized, especially to be used as learning materials in their implementation in educational institutions. Likewise, in the learning process, 
especially in the middle school level, multiculturalism has not been clearly integrated into the curriculum. This condition is increasingly exaced by the problems of the educators who are not enaugh understood to the concept of multiculturalism. Thus implicates the internalization process of multicultural values in the learning activities (Zein, 2014).

Edy (2017) conducted a study of elementary school book guidelines about multicultural. The results found that Islamic education and modernity should be done correctly and the most influential factor of it is the teacher. Herlina (2017) also conducted about Multicultural studies. She found that teachers who teach multicultural education are not only professionals of subjects taught but need to embed multicultural values in students, such as democratic values, pluralism, humanism and other values of diversity. Multicultural Studies in literature studies have not been able to find out the problem solving. Susanto (2011) found that multicultural education carried out in a sensitive integrative pattern and still not at a transformative level. The multicultural plot of Westerners is the difference in skin tone (Turner, 2020; Lopez \& Nikey, 2020). Talley-Matthews et al., (2020) reported that black lectures with the majority of whites. The results found that there was a difference in the skin that got treat in his lecture. So it is with educators who experience racial differences from students (Pratt \& Hanson, 2020). Assumptions about multicultural education in educational institutions from the results of the study still have not received serious attention. Hence, it is necessary to be addressed from the beginning. And the most major of multicultural education is cultural issues (Demeter, 2020). The diverse ethnic groups in Indonesia also affect the diversity of Indonesian culture. Thus, from research conducted by previous research on multicultural education either in theory or field studies still does not lead to a more serious about the importance of multicultural education conducted on Islamic educational institutions and how the strategies undertaken by educators in teaching multicultural education in Islamic religious education institutions.

\section{METHODS}

The research used a library research that focuses on the important issues surrounding the development strategy of multicultural Islamic education in Islamic educational institutions. The data collection techniques of this study are from journal articles and books relating to multicultural education, such as books and journals, written by Muliadi, (2011), Afif, (2012), Amar, (2010), Arif, (2017) and the other theories. Data analysis used two techniques, namely: 1) descriptive analysis, which is the effort to collect and compile data, then analyze the data; and 2) content analysis, which is aimed at the content analysis process in descriptive data. Content analysis is a research technique for making replicable inferences and validity of data by pay an attention to the context (Danandjaja, 2014). Meanwhile, the data analysis techniques used review of the literature, writes and summarizes from all the multicultural-related articles and books and also to study the books and articles related to other source data. 


\section{RESULT AND DISCUSSION}

\section{Multicultural Islamic Education Development}

Firstly, religious foundations. The diversity and distinction of human life according to Islam is Sunnatullah. The Qur'an as a representation of the messages of God to be a guide of mankind, has indeed given some important cues, both explicitly and implicitly about the existence of such diversity and differences. Among them can be seen in QS. Al-Hujurat [49]: 13, namely: O mankind, indeed We have created you from male and female and made you peoples and tribes that you may know one another. Indeed, the most noble of you in the sight of Allah is the most righteous of you. Indeed, Allah is Knowing and Acquainted.

It can be concluded that man is created consisting of men and women, Bersuku-suku and Berbangsa-bangsa, Ta'awun, and Tabayyun of their fellowmen. Human beings are as social creatures, so community life is a necessity. Through life that is collective as a society, of course there are many diversity or differences in various ways. Therefore, humans have since been created even from different wombs but in fact it is an interdependency (social) creature that interdependent with one another. Zubaedi (2015).stated that in response to the narrow thinking of some of his companions to the phenomena of skin differences and position, causing them to have a discriminatory view of others, is one of the problems that continues to happen today. The low attitudes of others, Primodialism (Ashabiyah), unprepared differently and treating others unfairly are among the attitudes that indicate the weakness of the multicultural spirit in people's lives.

The second was the historical basis. The first multiculturalism movement in Canada and Australia around the 1970's, followed later in the United States, Britain, Germany, and others, backed by the issue of racism and acts of discrimination against minority groups, especially addressed to people originating from Africa (Baidi, 2016). After decades, the multikulturalism discourse developed very quickly. Three decades since its rolling out, multiculturalism has undergone two important waves, namely multiculturalism in the context of different cultural recognition struggles and wave multiculturalism that legitimizes cultural diversity (Dunn, et.al, 2010). This implicates the increasingly pharmaceutics movement of multiculturalism in the life of nation and state. From the fact that the history shows that multiculturalism as a movement in the context of the plurality and values of humanity is a precisely judged movement and can be an alternative option in addressing various issues relating to the aspect of diversity. The positive response is indeed not independent of the human need for a concept that can organize and appreciate the plurality of life better and more meaningful. Third, the In psychology, the term human personality is known, namely the nature and behavior of a person that distinguishes it from the others as well as patterns of behaviour, interests, establishments, abilities and potentials owned by someone (Anwar, 2013). With a distinctive personality, the nature or character that human owned will surely differ from one another. The difference can be in 
many ways, such as wishes, feelings, hopes, goals and so forth, so that someone is in need of the recognition of the other people. But on the other hand, in one person also sometimes arises an attitude of primodialism. Primodialism is not only related to tribal fanaticism, but also related to group fanaticism or because of certain interests, so it sometimes encourages a person to be unrealistic in looking at a certain issue. Therefore, internalizing the values of multiculturalism needs to be done in a very broad way, so as not to be a potential conflict in community life.

Fourth, the foundation of Socio-cultural. The development of the society that has been in the era of the revolution of the 4.0 industry, certainly can not avoid the dynamics of differences or diversity (diversities). According to Dunn, et.al, (2010), These differences can at least be categorized into three things, namely: 1) subculture diversity, i.e. individuals or groups of people living with different perspectives and habits with a large community of values or cultures in general that apply; 2) Differences in perspectival diversity, i.e. individuals or groups with a critical perspective on mainstream value or established culture embraced by the majority of surrounding communities; and 3) Differences of communalities (communal diversity), i.e. individuals or groups living with genuine lifestyle (true) in accordance with their communal identity (indigeneous people way of life). In Indonesia, the emergence of conflict and violence is essentially due to the inability of individuals or groups of people to respond to differences or diversity that arise in the midst of their lives Therefore, multicultural education discourse becomes increasingly important for the efforts to maintain the unity and integrity of the nation, as well as for the sustainability of the united State of the Republic of Indonesia.

The Fifth was the geographical basis. For Indonesia as an archipelago, the reduced multiculturalism movement in education (Islam) is very important. With a number of $\pm 13,000$ large and small islands and a population of more than 200 million people consisting of 300-an tribe with almost 200 languages used (Baidi, 2016), This really requires a good concept of structuring so as not to clash with each other. Likewise, with a rich understanding and trust, in Indonesia also embrace diverse religions and beliefs, such as Islam, Catholic, Protestant, Hindu, Buddhist, Confucian, and various other beliefs and traditions. The fact of religious diversity at some point can turn out to be a very sensitive domain if it is not managed properly, especially for grass root groups that are psychologically very easily provoked on issues with SARA's tone. Likewise the traits of Primodialism, still become a difficult part to be eliminated in some groups in the community. From the explanation above, it can be emphasized that the foundations that can be used as consideration in the development of multicultural Islamic education on Islamic Educational institutions, is the one which is referring to several basic foundations, starting from the religious foundation (Islamic), historical, psychological, socio-cultural and geographic foundations. 


\section{The Strategy for Developing Multicultural Islamic Education in Islamic Education Institutions}

The development of multicultural Islamic education in Indonesia is undeniable to face various challenges, including: 1) Socio-cultural aspects, namely the emergence of opposition in the socialization and internalization of the values of multicultural education, especially from groups of people who tend to be textualist, both from Muslim and non-Muslim; 2) political aspects, namely the challenges of the policy determinant, both executive and legislative, because they do not yet have a common vision of developing multicultural Islamic education; 3) Aspects of education, namely from institutions or educational practitioners who still have different views on the urgency and implementation of multicultural Islam education;4) Globalization, the influence of globalization is so great against the order of the world community and also influence on religious life; 5) Islamic radicalism, which is a movement that maintains the existence and orthodoxy of religion with violent roads, so it tends not to desire the existence of diversity; and 6) Differences in views about religious and state relations are difficult to unite, thus affecting the development of multicultural education (Harahap, 2015).

In this regard, the development of multicultural Islamic education in Islamic education institutions must consider that the multicultural values that are inherently existed since the people of Indonesia exist through the philosophy of Indonesian nation Bhinneka Tunggal Ika, like Gotong Royong, assisting, and appreciating among others, is an important capital to develop multicultural Islamic education so that it becomes bigger and better, especially in Islamic education institutions (Harahap, 2015).

As a comparison, multicultural education that develops in western countries, such as the United States, is an educational process that emphasizes learning strategy by making the background of students a diverse culture as the basis for improving student learning in the classroom and school environment. This is done in order to support and expand the cultural concepts, differences, similarities, and democracy in the aspects of national and State life (Elkader, 2015). The implementation of multicultural education that takes place in America is positioning the diversity of students as an important factor that can support the implementation and development of multicultural education more broadly. For the Islamic educational institutions in Indonesia, several studies that are summarized in the foundation of the Development of multicultural Islamic education and the potential challenges that will be faced, can be a consideration in determining the strategy of development of multicultural Islamic education. The development strategy in question is certainly must make the principles of value contained in Islamic teachings as the main foundation in the development process. Quantitatively, the multicultural Islamic Education Development strategy that can be pursued is: first, the socialization and internalization program through scientific activities, by expanding references or reading materials about the development of multicultural Islamic Education (Zein, 2014). Such references or reading materials need to be arranged with 
respect to the target reader. Halidijah (2011) said that "Although information can be found from other media such as television and radio, the reading role cannot be completely replaced. Reading still plays an important role in everyday life, because not all the information is got from television and radio media. "By expanding the multicultural reading material tailored to the target audience, it will further expand the socialization process and the internalization of multicultural education in all circles.

The second, multicultural Education Innovation program. This Program can be done individually or in groups or involve a wider community. The implementation of Multicultural Education Innovation program needs to be adjusted to the environment and level of the group faced. A form of activity from a multicultural education innovation program, among them multicultural education through a holistic language program that can be applied to children in early childhood education institutions (Soekmono, 2017), Learning transformation with dialogue approach and development of tolerance in school environment (Maulani, 2012), Then multicultural character learning through psychological first Aid program aimed specifically at natural disaster victims (Yuwanto \& Khiat, 2015). To encourage innovation programs multicultural education can be sought through the activities of the competition, the involvement of forums or communities that concern on multicultural issues, seminar activities, counseling, and especially in school learning activities.

The third, build a culture that accommodates the spirit and multicultural values, both in the environment of Islamic and community education institutions. The development of multicultural cultures in the educational environment can be pursued through multicultural-based learning, so that the students ' attitudes and mindset will be more open to understanding and appreciating diversity. It is important to eliminate any form of discrimination practice (Halidijah, 2011). The development of multicultural culture in the community can be done by utilizing forum or Islamic education media, such as religious lectures, preaching Friday, Ta'lim assembly, public events and so on. Next qualitative development, the strategy that can be sought is: first, intensive assessment program to strengthen the Science building (epistemology) multicultural Islamic education. There are still many theories dominated by Western thinkers who are sourced from post-modernism philosophy. Therefore, there is a need for research that is based on Islamic sources (Qur'an and As-Sunnah) itself. Acording to Suparman, (2017), The Qur'anic view of multicultural is essentially already in Islam from the time of Rasulullah until now. The diversity is precisely the intellectual property to be examined, as stated in the Qur'anic verses that explain this (Yasin, 2019). Through multicultural education, it is hoped that every individual or group can receive and cherish every difference, coexistence peacefully and calmly, thus forming a peaceful and prosperous state and nation.

Conceptually, the Qur'anic view of multicultural consists of five characters, i.e. learning to live in the differences, building three aspects of mutual (mutual trust, understanding, and respect), open minded thinking, 
appreciation and interdependence, as well as resolution of conflict and reconciliation of violence. Thus, the concept of multicultural education is essentially very aligned with Islamic teachings, namely in regulating the human order of the Earth (Suparman, 2017; Syafe'i, 2017). Therefore, multicultural Islamic education has given a little hope in overcoming the various problems of society that occurred lately and it is also as an educational concept that always uphold the values, beliefs, heterogeneity, plurality, diversity, so that it needs deepened and excavated from sources of Islamic teachings, namely the Qur'an and As Sunah. (Harahap, 2015).

The second, the curriculum Revision program to strengthen the multicultural values in education programs, both at school and college. The current school-level curriculum, has not fully accommodated the spirit and multicultural values. Acording to Trianingsih (2017), among the main reasons to enter a multicultural education in the school program is to correct deficiencies in the preparation of the curriculum. The main objective of multicultural education is to learn about historical background, language, cultural characteristics, donations, critical events, influential individuals, and the social, political, and economic conditions of various ethnic groups and minorities. This information must be comprehensive, analyistic, and comparative, and should incorporate similarities and differences between the existing groups. The psychological foundation of multicultural education emphasizes the development of greater self-understanding, positive selfconcept, and pride in its personal identity. The emphasis of the field is part of a multicultural education objective that contributes to the personal development of students, which contains a better understanding of the self that ultimately contributes to the overall intellectual, academic, and social achievement of students.

The third, education and training programs to enhance educators' understanding of multicultural significance and urgency, and how educators can implement them in the teaching process. It should be recognized that some the educators themselves are still in low-minded about the dynamics of diversity and difference, so it takes an internalization effort among educators. This can be done by providing an intensive understanding of educators (Zein, 2014), i.e. through training, reading materials and a space of creativity to write about multicultural education. In the context of an inclusive teaching method of religious education, the relationship between teachers and learners is dialogicalcommunicative. Teachers are not viewed as the only source of learning, as well as vice versa. However, teachers and learners alike as subjects of learning, so the atmosphere of learning in the classroom will be dynamic and lively. Teaching of religious education is not only understood as a transfer of knowledge, but also a passion and practice in daily life. Religious teachings in turn have a close relevance to the real nature, not just the afterlife (occult).(Amar, 2010)

The fourth, the local Wisdom program, which is the development of local culture laden with moral values and does not contradict the basic principles of 
Islamic teachings. Substantially, local wisdom is the prevailing value and norm in a society that is believed to be true and is a reference in acting and everyday behavior. Local wisdom is human intelligence belonging to certain ethnic groups acquired through community experience (Desfandi, 2019). A multicultural education based on local wisdom, can be done with an Islamic deradicalisation program consisting of two phases, namely: 1) deradicalisation is carried out as early as possible by doing preventive measures against radicalunderstanding (preventive deraddaic), and 2) deradikalization is done through the preservation of Islamic comprehension lil'alamin (preservative deradicalization), thus developing a tolerant Islamic society and Love Peace (rahmatan lil'alamin). (Arif, 2017). Development of local culture in its implementation in the educational environment, can be done by giving the task to the students to participate in community activities or local cultural events that exist in the community (Zein, 2014). Especially for students, research programs and community service that has been integrated in education curriculum, need to be equipped with content or more specific multicultural values.

Thus, from several views on multicultural education, it is always closely related to religious, historical, psychological, sosio-kultural and geographic foundations. The foundation forms multicultural by looking at these aspects, so multicultural is not understood as a conflict. However, the distinction is the distinction of ethnicity, without conflict as taught by God, that God does not at all see the difference, but that distinguishes it is takwa. Therefore, in order to provide reinforcement to multicultural education in Islamic education institutions, it is necessary to do exercises related to multicultural education So that there is no discrimination for the students.

The Study of multicultural Islamic education has been conducted in many previous research studies, as has been mentioned at the end of the introduction, but the study conducted by previous research, such as Amar (2010), focuses on reviewing normative foundations related to Qur'anic verses as an inspiration for Islamic education in the multicultural era. Afif (2012) was reviewing the model of multicultural-based Islamic education that some figures were seen as the most suitable concept to apply in Indonesia. While, research on Azzuhri (2012) focuses on the concept of multiculturalism and pluralism in religious education. Zein (2014) also examined the development of multicultural Islamic education based on human resources management. The same as Harahap, (2015) conducted the background and development of multicultural education, multicultural education ideas, and multicultural-based Islamic education challenges. From the results of previous research studies, still did not discuss urgent about the foundation of the Development of multicultural Islamic Education and the strategy of development of multicultural Islamic education on Islamic educational institutions more specifically.

From the previous research, multicultural education conducted in educational institutions, either in Islamic or formal education. It was only touches on some aspects, not to the whole aspect, whether from educators, 
student's understanding about the differences and others. Therefore, as a teacher is not only required about social competence, pedagogic, personality, professional, but also demanded about cultural competence. It means that every educator who is assigned in certain areas with Islamic religion as a priority, so as teachers hopfully are not only teaching about the lesson material contained in the textbook, but also can use the hidden curriculum in every submission of materials conducted during the course.

\section{CONCLUSION}

Multicultral Education is an education that appreciates the differences. From the research results, it was discovered; First, the foundation of multicultural Islamic Education Development in Islamic education institutions refers to several fundamental foundations, namely religious, historical, psychological, sosio-kultural and geographic foundations. Secondly, the strategy for developing multicultural Islamic education in Islamic education institutions can be quantitative and qualitative. Quantitatively: a) the socialization and internalization Program through scientific activities; b) Multicultural education innovation Program; and c) Build a culture that accommodates spirit and multicultural values in the environment of Islamic education institutions. Qualitative is: a) intensive assessment Program to strengthen the science Building (epistemology) of multicultural Islamic education based on the Qur'an and Sunnah; b) curriculum revision Program; c) Education and training programs for educators; and d) Local wisdom program.

\section{ACKNOWLEDGMENTS}

This Research was a collaborative research with four institutions, namely Institut Agama Islam Sultan Muhammad Syafiuddin Sambas, Universitas Wijaya Putra Surabaya, Sekolah Tinggi Agama Islam Rasyidiyah Khalidiyah Amuntai, dan Institut Agama Islam Negeri Palanga Raya. The author thanked to lecturers who finished the research collaboration.

\section{AUTHOR CONTRIBUTION STATEMENTS}

The author had participated in the research and approved the final version of the manuscript

\section{REFERENCES}

Abd Elkader, N. (2015). Dialogic multicultural education theory and praxis: Dialogue and the problems of multicultural education in a pluralistic society. Dialogic Pedagogy: An International Online Journal, 3. https:// doi.org/10.5195/dpj.2015.71.

Afif, A. (2012). Model Pengembangan Pendidikan Islam Berbasis Multikultural. Tadris, Jurnal Pendidikan Islam, STAIN Pamekasan, 7(1), 1-18. Google Scholar 
Amar, I. (2010). Studi Normatif Pendidikan Islam Multikultural. Islamica, Jurnal Studi Keislaman, Pascasarjana Universitas Islam Negeri Sunan Ampel Surabaya, 4(2), 320-334. https: / / doi.org/10.15642/islamica.2010.4.2.320-334

Anwar. (2013). Kamus Psikolog, teori, hukum, dan konsep. Pionir Jaya. Google Scholar

Arif, M. (2017). Deradikalisasi Islam Melalui Pendidikan Multikultural Berbasis Kearifan Lokal pada Masyarakat Cigugur. Akademika, Jurnal Pemikiran Islam, LPPM IAIN Metro Lampung, 22(1), 51-75. https:// doi.org/10.32332/akademika.v22i1.716

Arifin, Z. (2018). Pendidikan Islam Multikultural Upaya Menumbuhkan Kesadaran Multikultural. Al-Insyiroh: Jurnal Studi Keislaman, 2(1), 38-56. https:// doi.org/10.35309/alinsyiroh.v2i1.3331

As-Suyuthi, I. (2018). Asbabun Nuzul: Sebab Sebab Turunnya Ayat-ayat Al-Qur'an. Qisthi Press. Google Scholar

Azzuhri, M. (2012). Konsep Multikulturalisme Dan Pluralisme Dalam Pendidikan Agama (Upaya Menguniversalkan Pendidikan Agama dalam Ranah Keindonesiaan). In Forum Tarbiyah (Vol. 10, No. 1, pp. 13-29). Fakultas Tarbiyah IAIN Pekalongan. Google Scholar

Baidi, B. (2016). Pendidikan Kewarganegaraan Berbasis Multikulturalisme Perspektif Psikologi Sosial Islam, CV Budi Utama. Google Scholar

Chin, C. (2019). The concept of belonging: Critical, normative and multicultural. Ethnicities, 19(5), 715-739. https:/ / doi.org/10.1177/1468796819827406.

Danandjaja, J. (2014). Metode Penelitian Kepustakaan. Antropologi Indonesia. https:// doi.org/10.7454/ai.v0i52.3318.

Demeter, M. (2020). Power relations in global knowledge production. A cultural/critical approach. Journal of Multicultural Discourses, 15(1), 1-17. https:/ / doi.org/10.1080/17447143.2019.1657124.

Desfandi, M. (2019). Kearifan Lokal SMONG Dalam Konteks Pendidikan: Revitalisasi Nilai Sosial-Budaya Simeulue. Syiah Kuala University Press. Google Scholar

Dunn, K. M., Kamp, A., Shaw, W. S., Forrest, J., \& Paradies, Y. (2010). Indigenous Australians' attitudes towards multiculturalism, cultural diversity,'race' and racism. Journal of Australian Indigenous Issues, 13(4), 1931. Google Scholar

Edy. (2017). Pendidikan Multikultural Di Sekolah Dasar (Studi Atas Buku Panduan Model Kurikulum Pendidikan Agama Islam Berbasis Multikultural Sekolah Dasar). Edukasi Islami: Jurnal Pendidikan Islam, 6(11), 22. https:/ / doi.org/10.30868/ ei.v6i11.97.

Ghosh, R., \& Galczynski, M. (2014). Redefining multicultural education: Inclusion and the right to be different. Canadian Scholars' Press. Google Scholar

Halidjah, S. (2011). Pemberian Motivasi Untuk Meningkatkan Kegiatan Membaca Siswa Sekolah Dasar. Jurnal cakrawala kependidikan, 9(1). Google Scholarx

Harahap, K. S. (2018). Paradigma Pendidikan Islam Berbasis Multikultural Di Pantai Timur Sumatera. Madania: Jurnal Ilmu-Ilmu Keislaman, 5(2), 129-151. Google Scholar 
Herlina, N. H. (2017). Pendidikan multikultural: upaya membangun keberagaman inklusif di madrasah/sekolah. Sabilarrasyad, 2(2). Google Scholar

Irawati, E., \& Susetyo, W. (2017). Implementasi Undang-Undang Nomor 20 Tahun 2003 Tentang Sistem Pendidikan Nasional Di Blitar. Jurnal Supremasi, 7(1), 3-3. https:/ / doi.org/10.35457/supremasi.v7i1.374.

Kurniallah, N., \& Suharti, S. (2016). Pendidikan Islam Berbasis Inklusifisme dalam Kehidupan Multikultur. Jurnal Penelitian, 10(1), 201-232. https:/ / doi.org/10.21043/jupe.v10i1.1337.

Lash, S., Featherstone, \& Mike (ed.). (2002). Recognition and Difference: Politics, Identity, Multiculture. Sage Publication.

Lee, C. C. (2019). Invite Their Languages In: Community-Based Literacy Practices with Multilingual African Immigrant Girls in New York City. International Journal of Multicultural Education, 21(2), 1-22. https:// doi.org/10.18251/ijme.v21i2.1800.

Lopez, L. (Licho) L., \& Nikey. (2020). 'Black girl magic, y'all can't stand it, y'all can't ban it': Black girl curated curricula unsettling the conventional reason of school. Race Ethnicity and Education, 0(0), 1-16. https:// doi.org/10.1080/13613324.2020.1718078.

Maulani, A. (2012). Transformasi Learning dalam Pendidikan Multikultural Keberagaman. Jurnal pembangunan pendidikan: Fondasi dan aplikasi, 1(1), 2944. Google Scholar

Maksum, A. (2007). Pendidikan Kewarganegaraan: Demokrasi, HAM, Civil Society dan Multikulturalisme. PuSAPoM.

Mazid, S. (2017). Rekonstruksi Pendidikan Kewargaan Multikultural Dalam Bingkai Keindonesiaan Yang Beradab. Literasi Hukum, 1(1)..Google Scholar

Mohammad Al Farabi, M. A. (2018). Pendidikan Orang Dewasa Dalam Al-Qur'an. Kencana. Google Scholar

Mujiburrahman. (2017). Agama Generasi Elektronik (Cetakan Pertama). Pustaka Pelajar. Google Scholar

Muliadi, E. (2011). Urgensi Pembelajaran Pendidikan Agama Islam Berbasis Multikultural di Sekolah. Jurnal Pendidikan Islam, 1(1), 55-68..Google Scholar

Mulyono, M. (2019). Pembelajaran Pendidikan Agama Islam Berbasis Multikultural. El-Wasathiya: Jurnal Studi Agama, 7(1), 45-62. https:// doi.org/10.5281/zenodo.3522418

Nuzliah. (2016). Counseling multikultural. Jurnal edukasi: Jurnal Bimbingan Konseling, 2(2), 201. https:/ / doi.org/10.22373/je.v2i2.816.

Pratt, Y. P., \& Hanson, A. J. (2020). Indigenous instructors' perspectives on preservice teacher education: poetic responses to difficult learning and teaching. Race Ethnicity and Education, 0(0), 1-19. https:// doi.org/10.1080/13613324.2020.1718085.

Sahal, M., Musadad, A. A., \& Akhyar, M. (2018). Tolerance in Multicultural Education: A Theoretical Concept. International Journal of Multicultural and 
Multireligious Understanding, 5(4), 115-122. https:// doi.org/10.18415/ijmmu.v5i4.212.

Soekmono, R. (2017). Pendidikan Multikultural Melalui Program Bahasa Holistik: Penelitian Pengembangan di Kelompok B Taman Kanak-Kanak Nasima Semarang. JPUD, Jurnal Pendidikan Usia Dini, 11(2), 308-322. https:// doi.org/10.21009/JPUD.112.09.

Suparman, H. (2017). Multikulturalisme dalam Perspektif al-Qur'an. Al Quds, Jurnal Studi al-Qur'an dan Hadis, 1(2), 185-204. Google Scholar

Susanto, E. (2011). Pelaksanaan pendidikan agama islam multikultural di rintisan sekolah bertaraf internasional sman 1 pamekasan. Nuansa: Jurnal Penelitian Ilmu Sosial Dan Keagamaan Islam, 8(2), 169-182. https:// doi.org/10.19105/nuansa.v8i2.11.

Syafe'i, I. (2017). Model Kurikulum Pesantren Salafiyah dalam Perspektif Multikultural. Al-Tadzkiyyah: Jurnal Pendidikan Islam, 8(2), 127-143. https:// doi.org/10.24042/atjpi.v8i2.2121.

Talley-Matthews, S., Wiggan, G., \& Watson-Vandiver, M. J. (2020). Outsider in the academy: experiences and perspectives of Caribbean women attending predominantly White institutions in the southeastern region of the United States. Race Ethnicity and Education, 0(0), 1-20. https:/ / doi.org/10.1080/13613324.2020.1718077.

Trianingsih, R. (2017). Pendidikan Dalam Proses Kebudayaan yang Multikultural di Indonesia. Tarbiyatuna, Jurnal Kajian Pendidikan Islam, 1(1), 1-12. Google Scholar

Turner, J. D. (2020). Freedom to aspire: Black children's career dreams, perceived aspirational supports, and Africentric values. Race Ethnicity and Education, 0(0), 1-26. https:/ / doi.org/10.1080/13613324.2020.1718074.

Yasin, N. (2019). Multikulturalisme di Indonesia Menurut Al-Qur'an. ATTURAS: Jurnal Studi Keislaman, 6(2), 254-271. https:/ / doi.org/10.33650/atturas.v6i2.684.

Yuwanto, L., \& Khiat, V. (2015). Pembelajaran Karakter Multikulturalisme Melalui Program Psychological First Aid Korban Bencana Alam. Google Scholar

Zein, H. (2013). Pengembangan Pendidikan Islam Multikultural Berbasis Manajemen Sumber Daya Manusia. Tadris, Jurnal Pendidikan Islam, IAIN Madura, 8(1), 108-124. Google Scholar

Zubaedi, M. A. (2015). Desain Pendidikan Karakter. Prenada Media. Google Scholar

\section{Copyright Holder :}

(C) Hifza, H., Antoni, A., Syakhrani, A., Hartati, Z. (2020).

First Publication Right :

(C) Jurnal Iqra' : Kajian Ilmu Pendidikan

This article is under:

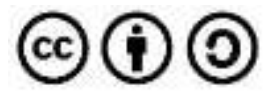

